Research, part of a Special Feature on Resilience and Vulnerability of Arid and Semi-Arid Social Ecological Systems

\title{
Coping with Multiple Stresses in Rural South Africa
}

\author{
$\underline{\text { Claire H. Quinn }}^{1}{ }^{\text {, Gina Ziervogel }}{ }^{2}$, Anna Taylor ${ }^{3}$, Takeshi Takama ${ }^{3}$, and Frank Thomalla ${ }^{4}$
}

\begin{abstract}
In this paper, we aim to investigate how local communities cope with and adapt to multiple stresses in rural semiarid South Africa. In semiarid regions water scarcity is one of a number of stresses that shape livelihood vulnerability. With climate change, it is predicted that rainfall in South Africa will become more uncertain and variable in the future, exposing more people to water insecurity. At the same time, the impacts of disease, a lack of institutional capacity, and limited livelihood opportunities can combine to limit adaptive capacity. Therefore, adaptation to changing climate should not be viewed in isolation but instead in the context of social, economic, and political conditions, all of which shape local community vulnerability and people's ability to cope with and adapt to change. This study uses a qualitativequantitative-qualitative framework, including the use of a stated preference survey, to identify the drivers of agroecosystem change, to understand the capacity of households to cope with droughts, and to determine the ability of local institutions to respond to crises. The analysis suggests that the capacity of the agroecosystem to remain productive during droughts is decreasing, individual/household adaptive capacity remains low, and institutional capacity faces considerable barriers that prevent it from supporting households to adapt to multiple stresses. This research adds weight to the claim that vulnerability reflects multiple forces and processes, and that multiple stresses, that are agroecological, socioeconomic, and institutional in nature, need to be examined to understand vulnerability and to prevent maladaptation.
\end{abstract}

Key Words: climate change; food security; multiple stressors; sub-Saharan Africa; vulnerability

\section{INTRODUCTION}

Over the past 20 years, studying how livelihoods, and in particular agricultural livelihoods, are vulnerable to a range of threats has emerged as an important body of literature. One approach has been to disaggregate the problems people face to focus on a single threat, such as drought or an increase in crop prices, to develop an in-depth understanding of the ways in which people respond and adapt. However, the reality is that social, economic, political, and biophysical factors interact to generate vulnerability and affect decision making in complex and dynamic social-ecological systems (Kasperson and Kasperson 2001, Adger 2006, Reid and Vogel 2006). In climate change research, it is increasingly recognized that adaptation decisions are not undertaken exclusively in response to changes in climate but involve trade-offs to reduce the risks from a range of interacting and dynamic stresses such as unemployment, inadequate basic services, food insecurity, and disease (Parry et al. 2005). Although communities and societies may have developed knowledge of and responses to environmental stresses such as droughts and floods (National Research Council 1999, Smit et al. 1999), changing climate patterns coupled with other problems such as a rise in diseases like HIV/AIDS and increasing demands for water, may expose people to new and unfamiliar conditions (African Development Bank et al. 2003, Thomas et al. 2005, Ziervogel and Taylor 2008). These new combinations of circumstances may also lead to more episodes when people are forced to sell assets to meet immediate needs, thereby increasing their long-term vulnerability (Watts 1983, African Development Bank et al. 2003).

Individual adaptation decisions tend to take place in the context of decision making processes at 
different geographic scales and institutional levels, across the public, private, and civil society spheres (Thomas et al. 2005, Reid and Vogel 2006). These processes may interact to produce unexpected outcomes that potentially conflict and increase vulnerability. For example, in response to late onset of the rains, individuals may delay planting food crops, while local governments may prioritize water supply to the commercial sector. This may lead to greater supply of food to local markets. However, individuals may be less capable of purchasing it without produce of their own to sell, and so become more food insecure. Therefore, research that investigates how people cope with multiple stresses, including climate change, must work within a framework that allows individual decisions to be situated within broader policy and land use changes.

In light of these challenges, this paper uses a mixture of qualitative and quantitative methods, including the use of a stated preference survey, to accomplish three key objectives: (1) to identify the drivers of agroecosystem change within the context of two rural villages in the Sekhukhune District of South Africa to determine whether the agroecosystem on which people depend is becoming more vulnerable to changes in weather patterns; (2) to understand the interaction of multiple stresses on the adaptation decisions of different households to demonstrate how these different stresses influence households' ability to cope with droughts; and (3) to determine the ability of local institutions to support individual/ household adaptation strategies in the study region. In meeting these objectives, this paper will provide empirical evidence that will enhance our understanding of vulnerable and complex agroenvironmental systems and how a range of possible stresses may increase the vulnerability of different households' livelihoods to climate change.

\section{SOUTH AFRICA CONTEXT}

Nowhere are the issues of livelihood vulnerability to multiple stresses more prevalent than in South Africa where extreme weather is common and both droughts and floods occur frequently (Department of Tourism 2004). In 2000, severe floods affected northern South Africa, Mozambique, and Zimbabwe causing 600 deaths and severely damaging infrastructure (Fauchereau et al. 2003). Research suggests that rainfall will become more intense and that droughts will become more frequent in the future (Fauchereau et al. 2003, Christensen et al. 2007). These trends have serious implications for water management that relies on large storage dams that are sensitive to changes in rainfall, runoff, and evaporation rates (Department of Tourism 2004). Even where groundwater is used, water table levels and recharge rates will also be affected by shifts in climate (Bouraoui et al. 1999). These effects will be compounded by the increased demands associated with hotter and drier conditions. Although the National Water Act has seen access to water in rural areas increase to $71 \%$ in 2006, this still leaves approximately 8.2 million people with inadequate or no access to piped water (Department of Environmental Affairs 2010).

Climate change is also expected to have significant health impacts in South Africa by increasing the risks of water-borne diseases such as cholera and diarrhea during intense rainfall events, dehydration during droughts, and strokes and skin cancers linked to higher temperatures (Department of Tourism 2004). This comes on the back of enormous existing health problems, particularly HIV/AIDS. Currently, 5.5 million people are living with HIV/AIDS in South Africa and approximately $18.8 \%$ of all adults aged 15-49 have the disease (UNAIDS 2006). As a result of HIV/AIDS and other diseases, life expectancy is only 49 for women and 47 for men (Haddad and Gillespie 2001). The result of this is that the number of working adults is decreasing, leaving children and the elderly with little or no household income (Drimie and Mousseau 2004). Caring for someone with HIV/AIDS also is a severe drain on household resources and savings, often leaving households on a "downward trajectory of struggle" (SADC FANR 2003:14). These factors combine to increase food insecurity in light of climate change by reducing their ability to produce or acquire food (Boudreau and Holleman 2002, SADC FANR 2003, Ziervogel and Drimie 2008).

\section{METHODS}

In this paper we follow Fraser (2007) and Fraser et al. (2011) in defining vulnerability to climate change as the consequence of agroecosystem capacity to absorb environmental stresses, the socioeconomic capacity of households to adapt, and institutional capacity to respond. This framework is useful for examining adaptation to multiple stresses in rural South Africa because, as Fraser et al. (2011) point out, the "social and ecological context is as important as the shock itself." The extent to which 
households are exposed to stress comes not only from the environmental stress itself, such as a lack of water because of drought, but from changes in agroecosystem conditions, from changes in their capacity to access resources (Sen 1981) that allow them to make adaptation decisions, and the extent to which collective responses through local and national institutions mitigate against environmental stresses (Ostrom et al. 1999, Ostrom 2001). As a result, understanding vulnerability becomes a process of understanding the impact of multiple stresses that are agroecological, socioeconomic, and institutional in nature.

Data were collected between January and February 2006 using a combination of qualitative and quantitative methods. To assess agroecosystem capacity, a review of qualitative data and current literature on agroecosystems in Sekhukhune District was carried out. Published literature and reports produced by the Food Insecurity and Vulnerability Information and Mapping Systems (FIVIMS) project were analyzed and coded in NVivo 8 (QSR International) according to the dimensions of diversity, connectivity, and productivity used in the Panarchy framework, to infer changes in resilience over time (Holling and Gunderson 2002). This was supported by coding of interview and focus group transcripts according to the same dimensions.

To assess household adaptation decision making, semistructured interviews were carried out with members from a purposively selected sample of households $(n=17)$ from two villages, Ga-Selala and Mohlotsi, based on participation in previous FIVIMS research. Most (14 out of 17) of the interviewees were women and some were household heads (9 out of 14) whereas the rest of the female interviewees had husbands who were working away from the village. These interviews established household characteristics, activities, sources of income and expenses, social networks, challenges to food security, coping and adaptation strategies, and sources of support. Coping strategies were defined as mostly short-term ways in which to deal with stresses, whereas adaptation strategies were considered to be longer term adjustments (Brooks et al. 2005). Following these interviews, two single gender focus groups were held in each village. In addition, a focus group was held in Mohlotsi with the members of various communal groups (total focus group $\mathrm{n}=100$ approx.). These focus groups also discussed challenges to food security, strategies for coping or adapting, and sources of support, with the aim of identifying consensus views. All interviews and focus groups were transcribed and transcripts were coded and analyzed to answer two key questions: (1) what are the important stresses to which people are exposed, and (2) how do they respond to these stresses?

Information from this qualitative research was then used to develop a stated preference questionnaire that asked people to choose different coping and adaptation strategies in response to a series of stress scenarios, for discrete choice analysis. Discrete choice methods have been developed in a range of disciplines over many years, but have become widely used in the transport sector (Ben-Akiva and Lerman 1985) where they can demonstrate the probability that certain modes of travel will be chosen and to investigate the influence that various factors have in that choice (Ben-Akiva and Lerman 1985). Discrete choice methods have also become increasingly popular in environmental research where researchers are interested in the choices that people make between alternatives, such as predicting demand for crops under alternative pricing and climatic conditions (Hope 2006). In discrete choice methods, each individual faces a choice from a set of options, and models of decision making are derived from the responses based on the assumption that normally people will adopt utilitymaximizing behavior, i.e., that individuals will choose between alternatives based on which will give them the best outcomes (Train 2009). The approach was used here to investigate the choice of coping and adaptation strategies made by 100 individuals in $\mathrm{Ga}$-Selala in response to a set of stress scenarios.

From the qualitative interviews we identified the following key stresses: (1) drought; (2) illness; and (3) higher maize prices. These stresses then became the basis of the stated preference questionnaire. In particular, we established a set of possibilities for each of these stresses that covered the range experienced by respondents. In the case of drought, this stress could either be present or not, whereas for length of illness and maize prices there were three possible alternatives. For the stated preference questionnaire, a series of nine different combinations of these stresses were presented to respondents as scenarios (Table 1) and respondents were asked to choose a strategy, from a predetermined list of strategies, they would likely adopt if confronted by the scenario. The strategies 
Table 1. Nine scenarios, based on stress and range of possibilities for each stress identified by respondents, presented in the stated preference questionnaire. $\mathrm{R}=$ South African Rand.

\begin{tabular}{|c|c|c|c|c|c|c|c|c|c|}
\hline Stress & Scenario 1 & Scenario 2 & Scenario 3 & Scenario 4 & Scenario 5 & Scenario 6 & Scenario 7 & Scenario 8 & Scenario 9 \\
\hline $\begin{array}{l}\text { Maize } \\
\text { price }\end{array}$ & $\begin{array}{l}\text { R40 less } \\
\text { than the } \\
\text { last price } \\
\text { paid }\end{array}$ & $\begin{array}{l}\text { R40 less } \\
\text { than the } \\
\text { last price } \\
\text { paid }\end{array}$ & $\begin{array}{l}\text { R40 less } \\
\text { than the last } \\
\text { price paid }\end{array}$ & $\begin{array}{l}\text { The same as } \\
\text { the last price } \\
\text { paid }\end{array}$ & $\begin{array}{l}\text { The same } \\
\text { as the last } \\
\text { price paid }\end{array}$ & $\begin{array}{l}\text { The same } \\
\text { as the last } \\
\text { price paid }\end{array}$ & $\begin{array}{l}\text { R40 more } \\
\text { than the last } \\
\text { price paid }\end{array}$ & $\begin{array}{l}\text { R40 more } \\
\text { than the } \\
\text { last price } \\
\text { paid }\end{array}$ & $\begin{array}{l}\text { R40 more } \\
\text { than the last } \\
\text { price paid }\end{array}$ \\
\hline $\begin{array}{l}\text { Length of } \\
\text { Illness }\end{array}$ & A day & One week & One month & A day & One week & One month & A day & One week & One month \\
\hline Drought & $\begin{array}{l}\text { Currently } \\
\text { not drought }\end{array}$ & $\begin{array}{l}\text { Currently } \\
\text { not drought }\end{array}$ & $\begin{array}{l}\text { Drought } \\
\text { conditions }\end{array}$ & $\begin{array}{l}\text { Drought } \\
\text { conditions }\end{array}$ & $\begin{array}{l}\text { Currently } \\
\text { not drought }\end{array}$ & $\begin{array}{l}\text { Currently } \\
\text { not drought }\end{array}$ & $\begin{array}{l}\text { Drought } \\
\text { conditions }\end{array}$ & $\begin{array}{l}\text { Currently } \\
\text { not drought }\end{array}$ & $\begin{array}{l}\text { Currently not } \\
\text { drought }\end{array}$ \\
\hline
\end{tabular}

were drawn from a total of seven coping and six adaptation strategies (Table 2) that were determined from analysis of the qualitative interviews and from observations by the UNRAVEL project (Casale et al. 2010). The stated preference questionnaire was translated into the local language (sePedi) and was completed by 100 individuals during a group exercise in which each question was explained in turn using short plays and descriptions (see Fig. 1). Incomplete questionnaires were omitted from the analysis leaving a sample number of 650 (65 questionnaires x 10 questions). The discrete choice analysis was carried out using the BIOGEME software package (Bierlaire 2003).

The third aspect of the method was to assess the capacity of local institutions to help households respond to crises. This was done using semistructured interviews that were carried out with government officials drawn from the Greater Marble Hall and Greater Tubatse municipalities and from Sekhukhune District authorities $(n=9)$. Interviewees included those involved in local development, community services, primary health care, water services, and environmental matters. The interviews were focused on identifying the issues that the respondents thought were of most concern at district, municipality, and village level, e.g., water scarcity, unemployment, etc., what activities were underway to address these issues, for example, public works programs, and how the issues might be tackled in the future. Climate, water, and health were highlighted where appropriate.

The combination of methods used in this study follows the "qual-quant-qual" framework described by Parker and Kozel (2004) for a similar study in India in which they identified this combination as a valuable methodological approach for understanding poverty and vulnerability. This approach is becoming increasingly common in situations whereby a grounded and contextually detailed understanding of a specific context, and a more general assessment of trends, are both important. Parker and Kozel undertook their qualitative fieldwork to inform the design of the quantitative portion of the research followed by further qualitative interviews to discuss and interpret the results. In the current study, we depart slightly from Parker and Kozel in that we used the second qualitative round to conduct interviews at the municipal and district scale. Although qualitative and quantitative approaches generate different types of information and are useful for answering different kinds of questions, they can be complementary if used in an integrated way.

\section{STUDY SITE}

Sekhukhune District, which covers an area of approximately 13,264 km² (Aird and Archer 2004), is high in biodiversity with over 2200 indigenous species of vascular plants in nearly 130 endemic or near endemic taxa found in a variety of bushveld and grassland habitats (Victor et al. 2005). It is formally designated as the Sekhukhuneland Centre of Plant Endemism (Van Wyk and Van Wyk 1997, Victor et al. 2005) and is located within the summer rainfall region of South Africa, receiving over $80 \%$ of its $500 \mathrm{~mm}$ to $800 \mathrm{~mm}$ of annual rainfall between November and March (Department of Water Affairs 
Table 2. Choice set of coping/adaptation strategies used in stated preference questionnaire.

\begin{tabular}{ll}
\hline \hline Coping strategies & Adaptation strategies \\
\hline Eat less preferred food & Work elsewhere \\
Reduce number of meals a day & Engage in village project \\
Limit portion size of meals & Contact district for support \\
Borrow food & Go on a training course at own cost \\
Eat elsewhere & Try to access a grant \\
Rely on piecework & Start/improve home garden \\
Purchase food on credit & \\
\hline
\end{tabular}

${ }^{\dagger}$ Piecework is short term, temporary work carried out for payment

and Forestry 2005). Inter- and intra-annual rainfall variability is high and both El Niño and La Niña events have significant influence on rainfall patterns. The major land uses are communal land (35\%), commercial agriculture (30\%), mining (15\%), and urban centers (15\%; Rule et al. 2005). Communal land is used to grow crops, graze cattle, and collect wild foods and traditional medicines (Victor et al. 2005). Commercial farming is concentrated on private land in the southwest and parts of the north of the district with crops grown under irrigation. Mining activities are generally located in the east where the rocks and soils hold some of the highest concentrations of heavy metals in the world including chromium, platinum, and titanium (Aird and Archer 2004).

Sekhukhune District is located in Limpopo province and is divided into five local municipalities: Fetakgomo, Greater Groblersdal, Greater Marble Hall, Greater Tubatse, and Makhuduthamaga. In 2003, there were just over one million people in the district with over $90 \%$ resident in rural areas (Aird and Archer 2004). Half the population is under the age of 18 (Department of Water Affairs and Forestry 2005). As in the rest of South Africa, HIV/AIDS have had a significant impact, reducing population growth rates to just over $1 \%$ in 2005 from $3.4 \%$ in the early 1980s (Department of Water Affairs and Forestry 2005). Employment levels are very low and large numbers of people are not economically active. Unemployment currently stands at $69 \%$, much higher than the provincial average of $49 \%$ (Greater Sekhukhune District Municipality 2005). Although the government employs some $16 \%$ of the population, most rely on government grants or remittances from family members working elsewhere. The main commercial activities in the district are mining and irrigated agriculture. Growth in both sectors is limited by water scarcity and uncertain land tenure. Currently $75 \%$ of land in Sekhukhune District is subject to land claims as part of the national land reform process (Greater Sekhukhune District Municipality 2005).

The two villages selected for this study were Mohlotsi and Ga-Selala, located in Greater Marble Hall and Greater Tubatse municipalities (Fig. 2, Table 3). The villages were selected based on their location and water infrastructure, i.e., tapped reticulated water in Mohlotsi, and communal standpipes from ground water in Ga-Selala. Mohlotsi is located to the north east of the town of Marble Hall and accessed via gravel roads. The estimated population in 2005 was 573 people (Department of Water Affairs and Forestry 2005). Ga-Selala is located on a main road to the northwest of Steelport. In 2005, its population was estimated at 2559 people (Department of Water Affairs and Forestry 2005). 
Fig. 1. Short play describing possible stress scenarios (left) and participants filling in the stated preference questionnaire (right).

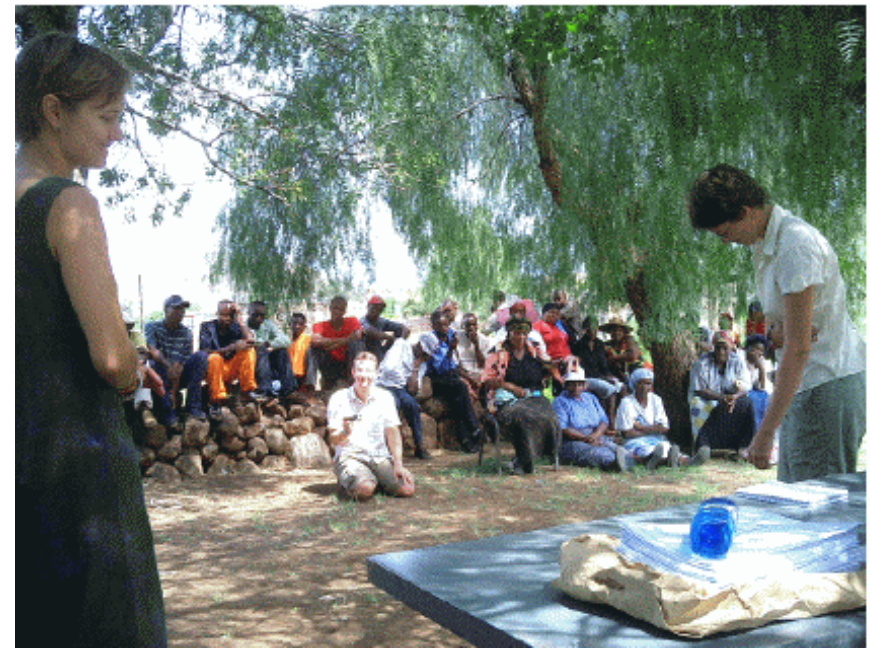

\section{RESULTS}

\section{Agroecosystem capacity}

Holling and Gunderson (2002) identify agroecosystem capacity as being influenced by diversity, connectivity, and productivity. Diversity contributes to the ability of the system to compensate for disturbance while maintaining function. Connectivity determines the speed of return to a prior state after disturbance and the strength of internal connections, while productivity relates to the accumulation of resources in the system. Table 4 shows a summary of evidence from the literature and qualitative data collected on the key drivers of vulnerability of the agroecosystem in Sekhukhune District to changes in weather patterns according to these factors.

Overall, these sources of information suggest that overgrazing of communal areas and the resultant bush encroachment is likely to be driving the system toward decreasing diversity (Victor et al. 2005, Zanner et al. 2004). Partly, this is because of overcrowding on communal lands and is a consequence of the apartheid system (Greater Sekhukhune District Municipality 2005), as well as a lack of clear policy and support for appropriate livestock management (Tefera et al. 2004). In agriculture, government policy has promoted

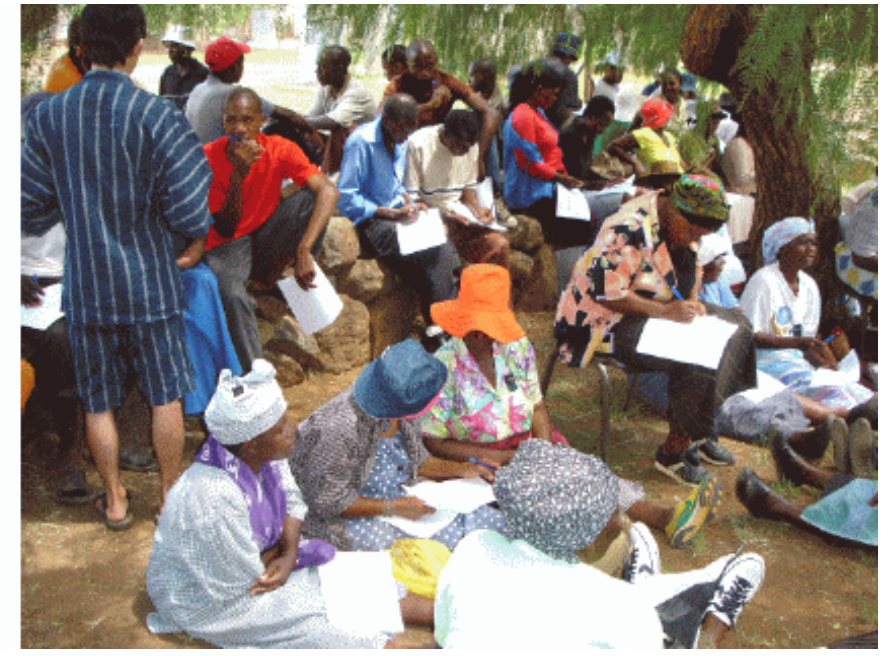

mono-cropping at a commercial scale whereas markets and social preferences have led maize to dominate in small-scale subsistence farming (Drimie et al. 2009). As a result, crop diversity across the region is also likely to be decreasing.

At the same time that vegetation and crop diversity is decreasing, low crop production and reduced yields are being reported (Stronkhorts and Pretorius 2008). Respondents reported that a key driver of low yields was a lack of sufficient rainfall. "It [the plot] only yields a small amount of food and then only when it rains. This is the first year for a while that the rains have been good" (villager from GaSelala).

The dominance of rainfed maize in small-scale farming means that harvests are kept low and a lack of access to productive land limits the scope for small-scale subsistence farmers to improve their yields (Greater Sekhukhune District Municipality 2005), particularly in the face of changing weather patterns. Current estimates suggest that only $35 \%$ of the population have access to land for agricultural activities (Rule et al.2005) and what communal land is available is subject to unsustainable use (Victor et al. 2005). Productivity in the ecological system has also been decreasing, with a reduction in palatable grasses, wild foods, and traditional 
Fig. 2. Map showing Sekhukhune District and the location of the two study villages (Source: UNEP/ GRID-Arendal).

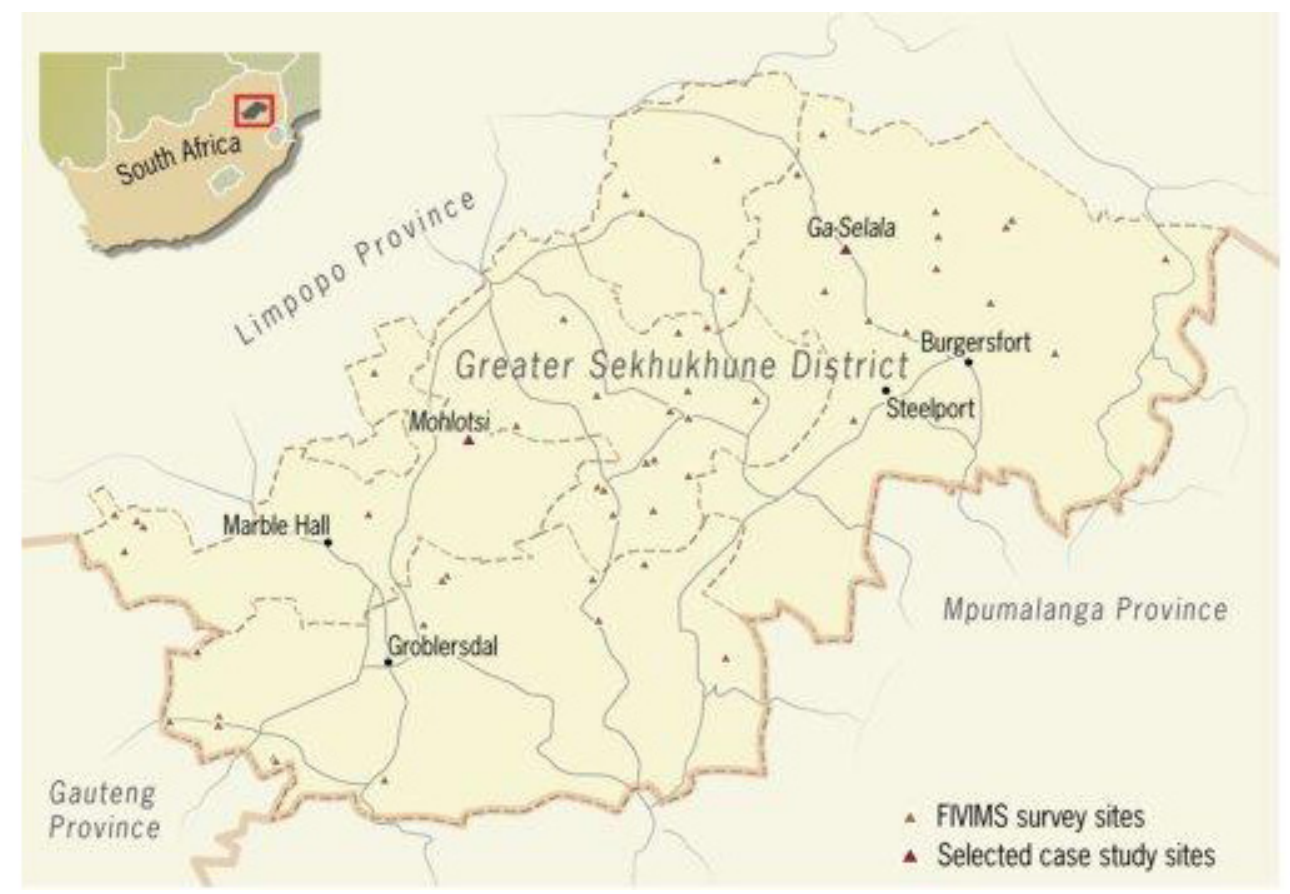

medicines (Victor et al. 2005). Respondents reported a shift in local diets away from traditional foods. "People ate homemade food made from sorghum and ingredients collected from the mountain so they were healthier and there was less disease around. Now people are eating sugar, beef, and maize meal with chemicals added" (villager from Ga-Selala). However, it was unclear if the decline of wild foods was due to a decline in availability or a shift in preferences by local households.

The ecology of many endemic species means that connectivity in the ecological system was low to begin with. Seed dispersal tends to be over short distances and most plants reproduce by vegetative or tuber propagation (Victor et al.2005). This makes it much more difficult for areas to recover from disturbance because of drought when land use changes through mining, commercial and subsistence agriculture have fragmented the system into smaller vegetation patches (Mucina and Rutherford 2006). In agriculture, a lack of rural infrastructure means that small-scale subsistence agriculture is less able to recover from disturbance such as drought (Gbetibouo et al. 2010). Although most commercial farms use irrigation systems to overcome drought, small-scale farmers use rainfed systems that have a greater vulnerability to drought, particularly if they rely on maize (Drimie et al. 2009). The ownership system in Sekhukhune District also contributes to fragmentation of the landscape. Land can be owned by the state, privately, or communally (Tefera et al. 2004) and each is managed differently for mining and urban expansion, commercial agriculture, or subsistence farming, respectively.

Key threats to the agroecological base come through expansion of state land for mining and housing, overuse of resources by commercial farming, and overcrowding leading to degradation in communal areas (Zanner et al. 2004, Victor et al. 2005). Mining, urbanization, and commercial farming also put increasing pressure on water resources in the region (Zanner et al. 2004) and water scarcity is likely to be an increasingly limiting factor. If future climate change leads to increased variability in 
Table 3. Village profiles of Mohlotsi and Ga-Selala, February 2006.

\begin{tabular}{|c|c|c|}
\hline & Mohlotsi & Ga-Selala \\
\hline Population (2005) & 573 & 2559 \\
\hline Water access & Piped water to each house & Six community taps \\
\hline Road access & $\begin{array}{l}\text { Tar and dirt roads }(\sim 50 \mathrm{~km} \text { from Marble } \\
\text { Hall) }\end{array}$ & $\begin{array}{l}\text { On main tarred road between Burgersfort } \\
(\sim 20 \mathrm{~km}) \text { and Driekop }\end{array}$ \\
\hline Healthcare & $\begin{array}{l}\text { Matlata hospital, mobile clinic, lack of } \\
\text { indoor examination facilities, frequent } \\
\text { lack of medication }\end{array}$ & $\begin{array}{l}\text { Mobile clinic, indoor examination } \\
\text { facilities, frequent lack of medication }\end{array}$ \\
\hline Housing & $\begin{array}{l}\text { Most dwellings are concrete structures, } \\
\text { high number of } \operatorname{RDP}^{\dagger} \text { houses }\end{array}$ & $\begin{array}{l}\text { Most dwellings are concrete structures, } \\
\text { several RDP }\end{array}$ \\
\hline Electricity & All houses & Most houses \\
\hline Sanitation & Pit latrines for most households & Pit latrines for most households \\
\hline Education & One primary school in the village & $\begin{array}{l}\text { One primary and one secondary school } \\
\text { in the village, several other schools in } \\
\text { the vicinity }\end{array}$ \\
\hline Irrigation & None & None \\
\hline Home garden & Some, with access to piped water & $\begin{array}{l}\text { Some, with access to dam water (when } \\
\text { pump is working) }\end{array}$ \\
\hline Crops & Mostly maize and sorghum & $\begin{array}{l}\text { Maize, sorghum, and vegetables } \\
\text { including pumpkins, moroho, tomatoes, } \\
\text { onions, beetroot, and watermelons }\end{array}$ \\
\hline Community projects & $\begin{array}{l}\text { Brickmaking, poultry, community } \\
\text { garden (failed) }\end{array}$ & Community gardening project (failed) \\
\hline Mining & None & Close proximity to platinum mines \\
\hline
\end{tabular}

${ }^{\dagger}$ RDP: Reconstruction and Development Programme

rainfall and more extreme rainfall events as expected (Fauchereau et al. 2003, Christensen et al. 2007), then small-scale subsistence agriculture is likely to become even more marginal. Already respondents are reporting changes in weather patterns in the region. "There used to be more people farming in the past when rainfall was better" (villager from Mohlotsi); "The main changes since I was young are there are now hotter temperatures and more scarce rainfall. Seasonal variation is increasing and the timing of the rainfall is changing" (villager from Ga-Selala).
Many households lack the capacity to compensate for the losses in ecological and agricultural resources through alternative livelihood activities. Therefore, although farming is becoming increasingly limited by changes in rainfall and other land management and policy drivers, many continue to attempt to grow crops or keep livestock. Overall, therefore, the evidence suggests an increasing level of vulnerability in the agroecosystem in this district such that in the future it is likely that relatively minor climate perturbations may have commensurately larger effects on the food produced by the region. 
Table 4. Summary of evidence from the literature and qualitative data showing the key drivers of vulnerability of the agroecosystem to changing weather patterns.

\begin{tabular}{|c|c|c|c|}
\hline & Diversity & Connectivity & Productivity \\
\hline Vegetation & $\begin{array}{l}\text { Overgrazing and degradation on } \\
\text { communal lands (Victor et al. } \\
\text { 2005, Zanner et al. 2004). } \\
\text { Bush encroachment on } \\
\text { communal lands (Victor et al. } \\
\text { 2005). }\end{array}$ & $\begin{array}{l}\text { Low dispersal and dominance of } \\
\text { vegetative reproduction in native } \\
\text { vegetation (Victor et al. 2005). } \\
\text { Cultivation, plantations, and } \\
\text { mining has led to a loss of } \\
\text { connectivity between vegetation } \\
\text { patches (Mucina and Rutherford } \\
\text { 2006). }\end{array}$ & $\begin{array}{l}\text { Decreasing palatable grasses, } \\
\text { wild foods, and traditional } \\
\text { medicines (Victor et al. 2005). } \\
\text { Perceived shift away from local } \\
\text { foods in diets (qualitative data). }\end{array}$ \\
\hline Agriculture & $\begin{array}{l}\text { Mono-cropping at a commercial } \\
\text { scale promoted by agricultural } \\
\text { policy (Drimie et al. 2009). } \\
\text { Small scale supplementary } \\
\text { farming dominated by maize } \\
\text { (Drimie et al. 2009). }\end{array}$ & $\begin{array}{l}\text { Heavy reliance on rainfed } \\
\text { agriculture (Stronkhorts and } \\
\text { Pretorius 2008; qualitative data), } \\
\text { which is slow to recover from } \\
\text { drought (Drimie et al. 2009). } \\
\text { Limited rural infrastructure } \\
\text { (Gbetibouo et al. 2010; } \\
\text { qualitative data). }\end{array}$ & $\begin{array}{l}\text { Low crop production and } \\
\text { reducing crop yields (Stronkhorts } \\
\text { and Pretorius 2008) Inadequate } \\
\text { rainfall limits yields (qualitative } \\
\text { data). }\end{array}$ \\
\hline $\begin{array}{l}\text { Land } \\
\text { management }\end{array}$ & $\begin{array}{l}\text { Overcrowding on communal } \\
\text { land limits the scope for land } \\
\text { reform (Greater Sekhukhune } \\
\text { District Municipality 2005). }\end{array}$ & $\begin{array}{l}\text { Mining expansion changing land } \\
\text { use in some areas (Aird and } \\
\text { Archer 2004). } \\
\text { Private, state, and tribal } \\
\text { (communal) land ownership } \\
\text { leading to fragmented } \\
\text { management (Tefera et al. 2004). }\end{array}$ & $\begin{array}{l}\text { Most fertile land privately owned } \\
\text { by commercial farmers limiting } \\
\text { scope for small farmers (Greater } \\
\text { Sekhukhune District Municipality } \\
\text { 2005). }\end{array}$ \\
\hline
\end{tabular}

\section{Individual capacity to adapt}

The key stresses on household food security identified by respondents were economic, i.e., increases in food prices; environmental, specifically drought; and health or illness. Economic and environmental stresses tend to be factors external to the household to which people respond, whereas health stresses work internally to reduce the capacity of households to be food secure. Although the evidence suggests that agroecosystem capacity may be declining in Sekhukhune District, most respondents did not report it explicitly as a major stress factor. Instead, declining rainfall was considered a serious issue for households with almost every respondent mentioning a lack of rainfall or erratic rainfall as a problem. Interestingly, drought was perceived to work through various routes to impact on households, for example, by contributing to increasing maize prices in local markets, by reducing the quantity of food produced from home gardens, and by increasing the prevalence of disease. "Economic reasons and drought have caused prices to go up" (villager from Ga-Selala); "More money is available when it rains, because we get produce from our home gardens and save on water bills" (villager from Mohlotsi).

Increasing food prices were considered an important stress factor because the majority of households surveyed spent between half and three quarters of their income on food, making them sensitive to changes in prices. Health stresses caused by illness or deaths were also considered to have serious consequences for households because of the extra costs for treatments and medicines. "My son has epilepsy and medicines are an extra expense that causes problems" (villager from Mohlotsi).

It could also be particularly difficult if the ill or deceased person was the major income earner in the family. There was also perceived to be an increase in health problems caused by a change from traditional foods to a diet of more processed foods. 
"Food makes people sick now because it contains chemicals whereas before the grandmothers used to make food" (villager from Mohlotsi).

Strategies to cope with or adapt to stresses draw on the range of assets and resources that households access (Adger and Vincent 2005), termed capital assets in livelihood studies (Carney 1998, Scoones 1998). Strategies were examined because they are a visible mobilization of adaptive capacity. The dominant asset that households in this study used was human, either through adjusting food intake or finding work to reduce the impact of a stress (Fig. 3 ). Spending less money on food or eating less during difficult times could be considered reasonable strategies when stresses are temporary and infrequent (Thomas et al. 2005), but these responses are short-term because they can lead to depletion of assets and increased longer term vulnerability. Social networks were also important assets that households used to help adjust household food intake and to find work. Borrowing food or sending family members to eat with better-off family members were often used as short-term coping strategies to overcome periods of food insecurity. In the longer term, social networks were used to reduce the risks of migration for work. Having social connections in urban centers reduced the risks and costs for migrants by helping them to find work and providing a place to stay, allowing more money to be sent back to the household. However, it is likely that the process of migration interconnects rural and urban risks. Movement to urban areas can lead to increased urban risks, often because of insecure informal settlements on marginal land, such as increased fire and flood risk, increased prevalence of disease, marginalization, discrimination, higher levels of unemployment, and additional strain on basic services. Migration as a rural adaptation strategy, therefore, has the potential to generate greater vulnerability elsewhere, but evaluating these indirect vulnerabilities are outside the scope of this paper.

One source of assets that households in Mohlotsi and Ga-Selala used in times of stress is not included in the five capital assets of Carney (1998) and Scoones (1998), i.e., that of institutional assets. Approaching the district for help, either directly or through support for community projects, or accessing government grants were both identified as strategies for dealing with difficult circumstances. Community projects were favored because villagers felt these had a better chance of being supported by government, although this perception was not supported by evidence of investment. These kinds of projects have potential because they benefit from the combined efforts of multiple actors and improved access to social, financial, and physical capital. Community projects also allow the risks of adopting a novel strategy to be shared, reducing the burden for individual households, and could potentially facilitate a transition from coping to adapting by providing more long-term strategies for dealing with stresses. However, even though many respondents believed such projects would provide the solutions to their problems, in reality most projects that have been instigated in the past failed because of a lack of investment or capacity.

The evidence for obtaining government grants for child support or as a pension for the elderly was far more widespread and successful. Many households were dependent on government aid and through such grants and pensions they could make up the majority of their income. Overreliance on these sources of income may have serious consequences for households as children grow too old to qualify for grants, or if elderly members die. Therefore, although they may reduce vulnerability initially, they may not be a long-term strategy.

Responses to stress are usually negotiated at the household scale resulting in a household strategy. This strategy usually consists of a range of actions, such as adjusting the household budget, migration, or accessing grants, which are then undertaken by individuals within the household. Diversification of activities at the household level can serve to reduce vulnerability by spreading the risks (Ellis 1998, 2000) and households who have diversified sources of income have been found to be more food secure (Rule et al. 2005). In one case, a respondent diversified their activities by taking on home-based care work, joining community projects, and restricting the household spending in response to economic stress. In most cases however, different actions were undertaken by different members of the household to contribute to a household strategy, in particular migration by a, usually, male family member in search of work. This strategy, if successful, can bring significant benefits through reduced reliance on rainfed agriculture. Diversification can be a positive strategy for some households, but it is also possible that diversification can lead to 'maladaptation' if the strategies are unsuitable or unproductive in the face of stresses (Smit et al. 2000). 
Fig. 3. Probability of three significant strategies being used when experiencing a drought.

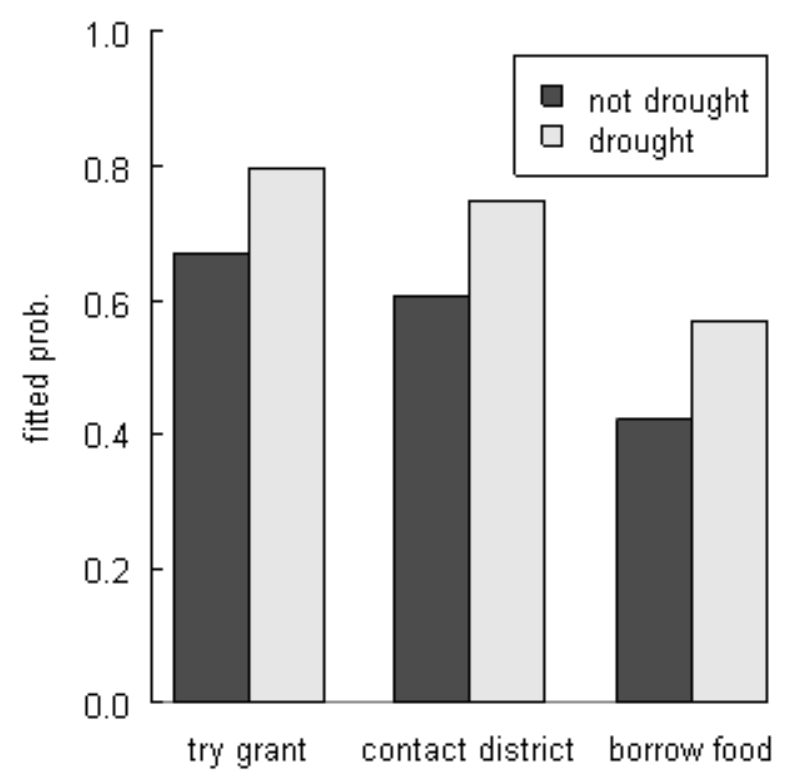

In the same way that households might undertake multiple actions in response to a specific stress, they also might undertake specific actions in response to a combination of stresses. To investigate this further, the stresses and response strategies identified by households were explored in more detail using the stated preference questionnaire and discrete choice analysis described in the methods section. Overall, the key result was that certain strategies were adopted by significant numbers of households when confronted by droughts or increases in maize prices but not for illness. More specifically, households were significantly more likely to adopt the adaptation strategies of accessing a grant or contacting the district for help, or the coping strategy of borrowing food, in the event of a drought ( $\mathrm{p}<0.05$; see table 5$)$. In contrast, only the coping strategies of eating elsewhere or eating less preferred foods were significant strategies for dealing with increasing maize prices $(\mathrm{p}<0.05$; see table 6). Households did not choose statistically significant strategies when asked how they would respond to multiple stresses, for example an increased maize price and an illness $(\mathrm{p}>0.05)$.

The positive values of $\beta$ in table 5 show that respondents were more likely to use these strategies during a drought. The positive values in $\alpha$ show that respondents generally found it difficult to borrow food or felt negatively about doing so, while the negative values mean that they felt positively about contacting the district or trying to access a grant. The probability of these three strategies being used was calculated based on the following equation.

$$
P \text { (use a strategy) }=\exp \left(U^{1}{ }_{i}\right) / \exp \left(U^{1}{ }_{i}\right)+\exp \left(U^{0}{ }_{i}\right)
$$

Where $\mathrm{P}$ is the probability and $\mathrm{U}^{1}{ }_{\mathrm{i}}$ is the unobserved utility function.

Among the three strategies, trying to access a grant was the most popular (Fig. 3). More than $67 \%$ of respondents said they would try to access a grant under nondrought conditions, but the probability increased to $80 \%$ during a drought, suggesting that the stress of drought drives greater demand for government support. Contacting the district and borrowing food were generally less popular strategies but the probability of these strategies being used in a drought increased by a similar magnitude from the nondrought situation.

Changes in maize prices were more likely to lead to members of the household choosing to eat 
Table 5. Binary logit model for significant strategy choices under drought conditions.

\begin{tabular}{|c|c|c|c|c|c|c|}
\hline \multirow[t]{2}{*}{ Strategy } & \multicolumn{3}{|c|}{ Not adopt strategy $(\alpha)$} & \multicolumn{3}{|c|}{ Drought $(\beta)$} \\
\hline & $\begin{array}{l}\text { Estimated } \\
\text { value }\end{array}$ & $\begin{array}{l}\text { Robust standard } \\
\text { error }\end{array}$ & Robust t value $^{\dagger}$ & $\begin{array}{l}\text { Estimated } \\
\text { value }\end{array}$ & $\begin{array}{l}\text { Robust standard } \\
\text { error }\end{array}$ & Robust t value $^{\dagger}$ \\
\hline Borrow food & 0.31 & 0.13 & 2.47 & 0.59 & 0.16 & 3.64 \\
\hline Contact district & -0.44 & 0.13 & -3.45 & 0.65 & 0.17 & 3.79 \\
\hline $\begin{array}{l}\text { Try to access a } \\
\text { grant }\end{array}$ & -0.70 & 0.13 & -3.35 & 0.67 & 0.18 & 3.64 \\
\hline
\end{tabular}

Number of observations $=650$

${ }^{\dagger}$ Robust $t$ values show the statistical significance of the parameters

elsewhere (Table 6). The change in maize price was calculated based on the maize price per pack (average pack size $65 \mathrm{~kg}$ ) that they had paid most recently. The positive value of $\beta$ means that respondents were more likely to eat elsewhere when maize price increased. The positive value of $\alpha$ means that they generally felt negatively about doing so or found it difficult to eat elsewhere.

If maize prices were converted into prices per kilogram based on their most recent purchase (to overcome variations in pack size purchased between respondents), the strategy of eating less preferred food became significant (Table 6 ). The positive $\beta$ means that respondents were more likely to eat less preferred foods when maize price increased. The positive value of $\alpha$ means that they generally felt negatively about doing so or found it difficult to eat less preferred foods.

The strategy of eating less preferred foods was a more popular strategy than eating elsewhere if maize prices remained stable $(26 \%$ respondents chose eating less preferred food compared with $13 \%$ choosing to eat elsewhere). When maize prices per pack increased by 40 South African Rand, only $1.5 \%$ more respondents were likely to choose to eat elsewhere whereas nearly $5 \%$ more respondents chose to eat less preferred foods. Overall, households were less sensitive to changes in maize prices than they were to drought.
Although there is some evidence to suggest that respondents' exposure to stresses is likely to be increasing because of declining and variable rainfall, increases in food prices, and more health problems, the impact on their capacity to adapt to stresses is less clear. There are a range of short-term and long-term strategies that households use to deal with stresses, from eating less to accessing grants. At the same time, households do not seem to be developing or using specific strategies to deal with the multiple stresses that they face, suggesting a lack of capacity to develop or employ new strategies. It is possible that in response to multiple stresses, households are choosing different strategies based on their own priorities and available assets, so no one strategy is significant. The lack of a clear strategy across all households for dealing with multiple stresses may also be the result of a lag between the impact of multiple stresses being felt and the emergence of a specific strategy to deal with them.

\section{Collective capacity of institutions}

The capacity of local institutions to provide support for households was generally weak, constrained in part by what Bohensky calls the "lingering consequences of past management actions" (2008:12). Under the previous homeland system, local government institutions were built around traditional chieftaincies (Aird and Archer 2004) 
Table 6. Binary logit model for the significant strategy choice under increasing maize price per pack and per kg. 'Eat elsewhere' was a significant strategy choice when the value per pack varied, whereas 'eat less preferred food' was significant when the price per kg varied.

\begin{tabular}{|c|c|c|c|c|c|c|}
\hline \multirow[t]{2}{*}{ Strategy } & \multicolumn{3}{|c|}{ Not adopt strategy $(\alpha)$} & \multicolumn{3}{|c|}{ Maize price (per pack and per $\mathrm{kg}^{\dagger} ; \beta$ ) } \\
\hline & $\begin{array}{l}\text { Estimated } \\
\text { value }\end{array}$ & $\begin{array}{c}\text { Robust standard } \\
\text { error }\end{array}$ & Robust t value ${ }^{\ddagger}$ & $\begin{array}{l}\text { Estimated } \\
\text { value }\end{array}$ & $\begin{array}{l}\text { Robust standard } \\
\text { error }\end{array}$ & Robust t value \\
\hline Eat elsewhere & 1.89 & 0.34 & 5.61 & 0.003 & 0.001 & 2.29 \\
\hline $\begin{array}{l}\text { Eat less preferred } \\
\text { food }\end{array}$ & 1.03 & 0.33 & 3.09 & 0.28 & 0.11 & 2.53 \\
\hline
\end{tabular}

Number of observations $=650$

$\dagger$ Pack $=$ average $65 \mathrm{~kg}$

$\ddagger$ Robust t values show the statistical significance of the parameters

before the post 1994 central government developed a democratic local government structure of wards, local municipalities, districts, and provinces with elected councilors. However, these new structures did not entirely replace the traditional institutions, which have endured the political transition and still retain some authority in rural areas, and instead have had to work alongside them. The coexistence of these two different governance structures has given rise to tensions and conflict because of differences in effectiveness and fairness, differences in local support, and confusion over their respective roles and responsibilities. "People don't understand the structure. The spheres of government are not clear to the public" (Integrated Development Plan officer).

Poor communication between levels of government, and between government and local citizens, were highlighted as barriers to adaptive capacity. There was frustration that government officials at ward, municipal, and district levels lacked information or authority to make certain decisions. At the same time, and likely because of this lack of clarity between the roles of government at different scales, people in the villages lacked awareness about who to approach with their problems or requests for support. As a result, there was the perception at the village level that their needs were not being met by these dual governance structures.

A second barrier to collective capacity was the mismatch in priorities between local government and local communities. Although the national discourse about the provision of resources such as water may have changed (Bohensky 2008) to prioritize those denied in the past, the reality was that the supply of resources such as water was still focused on the traditional recipients. The municipalities tended to focus on broad scale development opportunities with priorities to support water supply to commercial agriculture, tourism, and the mining sector. Local people were unaware of how their needs fitted into these broader plans and instead wanted direct investment aimed at generating local opportunities. Part of the problem was that local government did not consider it feasible or sustainable to support the agriculture schemes villagers wanted because there was not enough water to go around and priorities were being driven by national needs. However, these priorities were never effectively communicated to local communities. Instead, programs such as the public works program were developed to train and employ in infrastructure works, home-based care, and for the mining sector. However, the reality was that the public works program did not pay the participants and many found access to jobs in the mining sector extremely limited. "We used to get hired for temporary jobs like cleaning, cutting trees and fixing roads but now we are expected to volunteer" (villager from Mohlotsi); "It is difficult for people to get work in the local mines because the recruiter is from another village and so discriminates against us" (villager from Gal-Selala). 
Where investments had been made in small-scale projects such as communal gardens and brick making, they had failed to become self-sustaining because of the lack of interest at the municipal level in providing long-term financial and management support. "Have you seen projects that help village people? There don't seem to be projects that really help people. The majority have negative impacts. The purpose of the project is not met and when handed over they are not sustained. People are not consulted first" (Municipal officer).

Although institutional capacity is limited in some sectors, others have seen improvements. Disaster management plans have been developed with advisory forums to improve procedures for reducing the risks of and improving the response to disasters such as fire, flooding, and disease outbreaks. Sekhukhune District has also been the location of a pilot Food Insecurity and Vulnerability Information and Mapping Systems (FIVIMS) project carried out by the national government supported by the Food and Agriculture Organization (FAO) to map livelihoods, poverty, food insecurity, and vulnerability to develop early warning systems and help target interventions (FIVIMS 2009). These improvements have the potential to provide support and assistance to help households cope during times of major stress but they are less likely to support households in terms of adaptation to changing weather patterns.

In summary, the capacity of institutions to support adaptation to stresses is generally low because of a lack of clarity in roles and responsibilities and limited communication across scales of governance. Although there is some institutional capacity to deal with major disasters or shocks, the capacity for dealing with current and chronic stresses is still lacking. "The fact that people have to migrate [for work] means that the real issues have not been addressed" (Municipal officer).

\section{DISCUSSION}

This study has examined the agroecological, individual, and institutional factors that influence household food security in Sekhukhune District in South Africa. By doing so, it is possible to construct a trajectory through the three dimensional space proposed by Fraser (2007) and Fraser et al. (2011; Fig. 4). The evidence from literature, qualitative interviews carried out at local, municipal, and district scales, and quantitative analysis of the stated preference questionnaires suggests that vulnerability is moving toward the bottom far left corner of the cube as the agroecosystem's capacity to remain productive under changing weather patterns decreases because of a range of drivers, and because individual/household adaptation decisions are limited for multiple stresses, and institutional capacity faces some considerable barriers between the municipal and local scales. This suggests that future environmental stresses may overcome the natural resilience of the agroecosystem or households' own adaptive capacity, and that although in some ways they are better equipped today than in the past to avert crises, formal institutions are not structured to deal with chronic stresses. This research adds weight to the claim that vulnerability reflects multiple forces and processes, and that multiple stresses, which are agroecological, socioeconomic, and institutional in nature, need to be examined to understand vulnerability and to prevent maladaptation (Westerhoff and Smit 2009, Silva et al. 2010).

The results suggest that individuals and households may prioritize stresses to respond to them rather than choosing specific responses for multiple stresses. Our results show that households do not select specific strategies in response to scenarios that combine stresses, e.g., increase in maize price and illness, but they do when they are considered separately, except for illness where no strategy was significant. Households were more sensitive to droughts than to increases in maize prices or illnesses. They also tended to choose longer term adaptation strategies for dealing with drought conditions. This may well be because of the perception that drought is the result of a long-term decline in rainfall, a perception that is supported by recent research (Fauchereau et al. 2003, Christensen et al. 2007). Households were less sensitive to increasing maize prices and tended to choose shortterm coping strategies when prices increased, possibly the result of short-term price fluctuations related to harvests and the quantity of maize available in markets. Although many were aware of the link between droughts and maize prices, it was not reflected in their sensitivity to the scenarios or their choice of strategy. It is possible that trade-offs are being made between the multiple stresses that people face (Parry et al. 2005) for them to select from available responses. It may also be the case that those trade-offs are different for different households resulting in no one strategy being 
Fig. 4. Trajectory through vulnerability space for Sekhukhune District based on agroecosystem capacity, individual/household capacity, and institutional capacity to cope with stresses (Adapted from Fraser 2007).

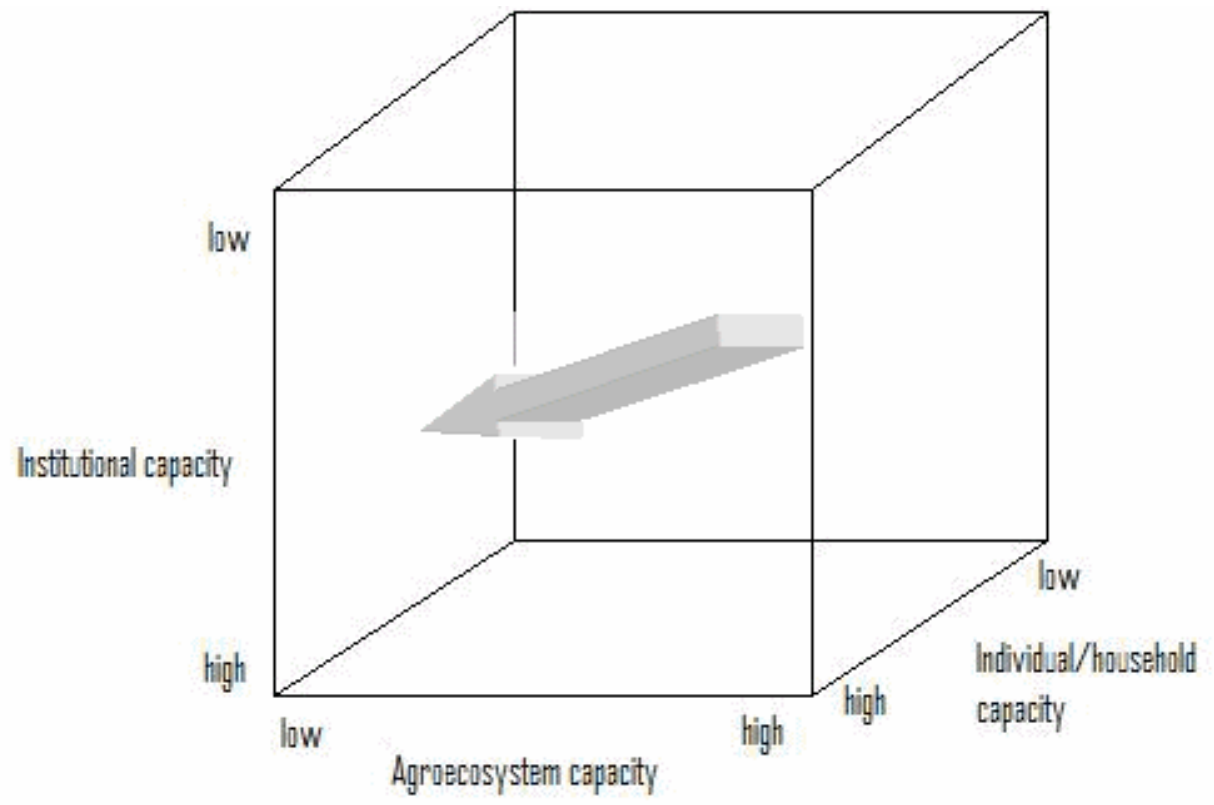

preferred. It may also be that with exposure to new and unfamiliar combinations of stresses there may be a lag before new adaptive strategies can emerge, although whether such a lag exists is at this stage speculative. However, if a lag exists then these new combinations of stresses may overtax current adaptive strategies, reducing assets and increasing vulnerability in the longer term before it is possible for households to develop new ways of coping and adapting (Watts 1983, African Development Bank et al. 2003). The limitations of this research lie in the restricted scale and scope of the case study, which means that the implications of some of the results are speculative at this stage. The ability to scale-up the conclusions to draw general lessons on vulnerability to multiple stresses, considering tradeoffs and time-lags, will require a broader range of in-depth case studies.

The policy implications of this research are twofold. First, there is a need to protect remaining land from development by mining, commercial agriculture, or urbanization. Without this protection, land use change is likely to continue to cause declines in agroecological resilience. At the same time renewed focus is needed on communal forms of management to halt overuse and degradation in communal areas. However, uncertainty in tenure and extensive land claims present major challenges for both (Greater Sekhukhune District Municipality 2005). Second, adaptation strategies at the village level must be embedded in and supported by adaptation planning at the local municipality and district level to address the potential conflicts that can contribute to increasing vulnerability of households (Thomas et al. 2005). One-off village level projects, with limited funding and no long-term support, are unlikely to be enough to increase the capacity of communities to adapt. Research by O'Brien et al. (2004) has shown that institutional barriers play an important role in preventing adaptation to multiple stresses. What is needed is a multiscale and integrated approach that links certain village level projects together, supports collaboration between institutions at various levels, and involves extensive engagement and deliberative decision making between a range of different stakeholders. This research has shown that currently a lack of 
communication across scales, uncertain authority, and the tension between traditional and elected leaders all act as significant barriers to improving institutional, community, and household adaptive capacity in the district and also make an integrated approach difficult to implement. This paper also highlights the importance of the district scale in facilitating adoption of national policy. Much research on adaptation to climate change has focused on local projects or national priorities. However, as this research shows, implementation of policy and support for vulnerable groups often happens, or does not happen, at the district level. Strengthening local governance at the district level is therefore necessary to facilitate adaptation action and success.

The impact of water insecurity, rather than climate change, has emerged as a significant stress at all levels, i.e., village, local municipality, and district. Water resources are directly impacted by fluctuations and changes in the climate and future projected climate change is expected to negatively affect these resources significantly (Schulze and Tyson 1997, Arnell 1999, Schulze 2005, de Wit and Stankiewicz 2006). As a result, water stress will continue to be a major factor limiting agroecological resilience and individual adaptive capacity in Sekhukhune District in the future. A focus on water management options at all scales must therefore be a priority in adaptation planning.

\section{CONCLUSIONS}

The objectives of this paper were to identify the drivers of agroecosystem change, to understand the interaction of multiple stresses and how they impact on household adaptive capacity, and to determine the ability of local institutions to support individual/ household adaptation strategies in Sekhukhune District, South Africa. Declining and increasingly variable rainfall is a key driver of both the likely downward trend in agroecosystem resilience and continuing low levels of individual/household adaptive capacity. The impact of multiple stresses on household adaptive capacity remains unclear as households prioritize stresses. There may be a lag before new coping and adaptation strategies emerge, leaving households vulnerable to a reduction in their already low asset base. Further, research is needed to determine if new strategies will indeed emerge and what the consequences will be for household food security in the interim. There is evidence that institutional capacity for supporting households is growing for disaster preparedness but that the barriers between the local and district levels mean that institutional capacity to support adaptation to chronic stresses is lacking. What is clear is that understanding the context of and interaction between agroecological, household, and institutional conditions in complex systems is key to understanding vulnerability.

Responses to this article can be read online at:

http://www.ecologyandsociety.org/voll6/iss3/art2/responses/

\section{Acknowledgments:}

The authors would like to thank Mandla Msibi who facilitated much of the work, the volunteer assistants from Mohlotsi and Ga-Selala, and the respondents from the villages, district, and municipality who shared their time and knowledge. We also thank the FIVIMS team for enabling us to build on previous research through access to maps and data, and Hugo Ahlenius from UNEP/GRID-Arendal for use of the map. This research was carried out as part of the Sida-funded SEI Poverty and Vulnerability Programme and was linked to the CAVES EU project. Claire Quinn was funded under an Economic and Social Research Council (ESRC) post-doctoral fellowship (PTA-026-27-0718) during the fieldwork and subsequently by the ESRC Centre for Climate Change Economics and Policy at the University of Leeds.

\section{LITERATURE CITED}

Adger, W. N. 2006. Vulnerability. Global Environmental Change 16:268-281. http://dx.doi.o $\mathrm{rg} / 10.1016 / \mathrm{j} . g l o e n v c h a .2006 .02 .006$

Adger, W. N., and K. Vincent. 2005. Uncertainty in adaptive capacity. C. R. Geoscience 337:399-410. http://dx.doi.org/10.1016/j.crte.2004.11.004

African Development Bank, Asian Development Bank, Department for International Development UK, Directorate-General for Development European Commission, Federal Ministry for Economic Cooperation and Development Germany, Ministry of Foreign Affairs-Development Cooperation The 
Netherlands, Organization for Economic Cooperation and Development, United Nations Development Programme, United Nations Environment Programme, and World Bank. 2003. Poverty and climate change: reducing the vulnerability of the poor through adaptation. World Bank, Washington, D. C., USA.

Aird, R., and E. Archer. 2004. Sekhukhune background document. FIVIMS ZA report. Kayamandi Development Services and Climate Systems Analysis Group, University of Cape Town, South Africa.

Arnell, N. W. 1999. Climate change and global water resources. Global Environmental Change 9 (1):31-49. http://dx.doi.org/10.1016/S0959-3780(99) $\underline{00017-5}$

Ben-Akiva, M., and S. Lerman. 1985. Discrete choice analysis: theory and application to travel demand. MIT Press, Cambridge, Massachusetts, USA.

Bierlaire, M. 2003. BIOGEME: A free package for the estimation of discrete choice models. Proceedings of the 3rd Swiss Transportation Research Conference, Ascona, Switzerland. [online] URL: http://infoscience.epfl.ch/record/117133/ files/bierlaire.pdf?version $=1$

Bohensky, E. L. 2008. Discovering resilient pathways for South African water management: two frameworks for a vision. Ecology and Society 13(1): 19. [online] URL: http://www.ecologyandsociety.org/ vol13/iss 1/art19/

Boudreau, T., and C. Holleman. 2002. Household food security and HIV/AIDS: exploring the linkages. The Food Economy Group, Pittsburgh, Pennsylvania, USA. [online] URL: http://v4.fews.n et/docs/Publications/1000087.pdf

Bouraoui, F., G. Vachaud, L. Li, H. Le Treut, and T. Chen. 1999. Evaluation of the impact of climate changes on water storage and groundwater recharge at the watershed scale. Climate Dynamics 15 (2):153-161. http://dx.doi.org/10.1007/s003820050274

Brooks, N., W. N. Adger, and P. M. Kelly. 2005. The determinants of vulnerability and adaptive capacity at the national level and the implications for adaptation. Global Environmental Change
15:151-163. http://dx.doi.org/10.1016/j.gloenvcha. 2004.12.006

Carney, D. 1998. Implementing the sustainable rural livelihoods approach. In D. Carney, editor. Sustainable livelihoods: what contribution can we make? Department for International Development, London, UK.

Casale, M., S. Drimie, T. Quinlan, and G. Ziervogel. 2010. Understanding vulnerability in southern Africa: comparative findings using a multiplestressor approach in South Africa and Malawi. Regional Environmental Change 10:157-168. http: //dx.doi.org/10.1007/s10113-009-0103-y

Christensen, J. H., B. Hewitson, A. Busuioc, A. Chen, X. Gao, I. Held, R. Jones, R. K. Kolli, W.-T. Kwon, R. Laprise, V. Magaña Rueda, L. Mearns, C. G. Menéndez, J. Räisänen, A. Rinke, A. Sarr, and P. Whetton. 2007. Regional climate projections. Chapter 11 in S. Solomon, D. Qin, M. Manning, Z. Chen, M. Marquis, K. B. Averyt, M. Tignor, and H. L. Miller, editors. Climate change 2007: the physical science basis. Contribution of Working Group I to the Fourth Assessment Report of the Intergovernmental Panel on Climate Change. Cambridge University Press, Cambridge, United Kingdom and New York, New York, USA.

Department of Environmental Affairs. 2010. State of the environment. Department of Environmental Affairs, Pretoria, South Africa. [online] URL: http: //soer.deat.gov.za/

Department of Tourism. 2004. A national climate change response strategy for South Africa. Department of Tourism, Pretoria, South Africa. [online] URL: http://unfccc.int/files/meetings/seminar/ application/pdf/sem sup3 south africa.pdf

Department of Water Affairs and Forestry. 2005. Water services planning reference framework, Sekhukhune District Municipality. DWAF, inviromap and GPM Consultants, Pretoria, South Africa.

De Wit, M., and J. Stankiewicz. 2006. Changes in surface water supply across Africa with predicted climate change. Science 311(5769):1917-1921. htt p://dx.doi.org/10.1126/science.1119929

Drimie, S. , T. Germishuyse, L. Rademeyer, and C. Schwabe. 2009. Agricultural production in Greater Sekhukhune: the future for food security in a 
poverty node of South Africa? Agrekon 48 (3):245-275.

Drimie, S., and F. Mousseau. 2004. Food security in Southern Africa - reviewing the response to the crisis of 2001-02, disentangling the underlying causes and charting the way forward. Oxfam, Oxford, UK.

Ellis, F. 1998. Livelihood diversification and sustainable rural livelihoods. In D. Carney, editor. Sustainable rural livelihoods: what contribution can we make? Department for International Development, London, UK.

Ellis, F. 2000. The determinants of rural livelihood diversification in developing countries. Journal of Agricultural Economics 51(2):289-302. http://dx.do i.org/10.1111/j.1477-9552.2000.tb01229.x

Fauchereau, N., S. Trzaska, M. Rouault, and Y. Richard. 2003. Rainfall variability and changes in Southern Africa during the 20th Century in the global warming context. Natural Hazards 29:139-154. http://dx.doi.org/10.1023/A:1023630924100

Food Insecurity and Vulnerability Information and Mapping Systems (FIVIMS). 2009. National FIVIMS launched in the republic of South Africa. FAO, Agricultural Development and Economics Division, Rome, Italy. [online] URL: http://www.fi vims.org/index.php?option $=$ com content\&task= blogcategory \&id=67\&Itemid=112

Fraser, E. D. G. 2007. Travelling in antique lands: using past famines to develop an adaptability/ resilience framework to identify food systems vulnerable to climate change. Climatic Change 83:495-514. http://dx.doi.org/10.1007/s10584-007$\underline{9240-9}$

Fraser, E. D. G., A. J. Dougill, K. Hubacek, C. H. Quinn, J. Sendzimir, and M. Termansen. 2011. Assessing vulnerability to climate change in dryland livelihood systems: conceptual challenges and interdisciplinary solutions. Ecology and Society 16 (3): 3. http://dx.doi.org/10.5751/ES-03402-160303/

Gbetibouo, G. A., C. Ringler, and R. Hassan. 2010. Vulnerability of the South African farming sector to climate change and variability: an indicator approach. Natural Resources Forum 34:175-187. http://dx.doi.org/10.1111/j.1477-8947.2010.01302. $\underline{x}$

Greater Sekhukhune District Municipality. 2005. Greater Sekhukhune District Municipality: 2004/2005 IDP review. Greater Sekhukhune District Municipality, South Africa. [online] URL: http://w ww.sekhukhune.gov.za/sekhukhune pdf/

Sekhukhune IDP.pdf

Haddad, L., and S. Gillespie. 2001. Effective food and nutrition policy responses to HIV/AIDS: what we know and what we need to know. International Food Policy Research Institute, Washington, D.C., USA. http://dx.doi.org/10.1002/jid.799

Holling, C. S., and L. H. Gunderson. 2002. Resilience and adaptive cycles. Pages 25-62 in L. H. Gunderson and C. S. Holling, editors. Panarchy: understanding transformations in human and natural systems. Island Press, Washington, D.C., USA.

Hope, R. 2006. Evaluating water policy scenarios against the priorities of the poor. World Development 34(1):167-179. http://dx.doi.org/10.1 016/j.worlddev.2005.07.014

Kasperson, J. X., and R. E. Kasperson. 2001. International workshop on vulnerability and global environmental change: a workshop summary. Stockholm Environment Institute, Stockholm, Sweden.

Mucina, L., and M. C. Rutherford, editors. 2006. The vegetation of South Africa, Lesotho and Swaziland. Strelitzia, Pretoria, South Africa.

National Research Council. 1999. Making climate forecasts matter. National Research Council, Washington, D.C., USA.

O’Brien, K., R. Leichenko, U. Kelkar, H. Venema, G. Aandahl, H. Tompkins, A. Javed, S. Bhadwal, S. Barg, L. Nygaard, and J. West. 2004. Mapping vulnerability to multiple stressors: climate change and globalization in India. Global Environmental Change Part A 14(4):303-313.

Ostrom, E. 2001. Environment and common property institutions. Pages 4560-4566 in $\mathrm{H}$. Baltus and N. Smelser, editors. International Encyclopaedia 
of the Social \& Behavioural Sciences. Elsevier Science, Oxford, UK.

Ostrom, E., J. Burger, C. Field, R. Norgaard, and D. Policansky. 1999. Revisiting the commons: local lessons, global challenges. Science 284:278-282. http://dx.doi.org/10.1126/science.284.5412.278

Parker, B., and V. Kozel. 2004. Understanding poverty and vulnerability in India's Uttar Pradesh and Bihar: a mixed method approach. In Proceedings of Conference on Experiences of Combining Qualitative and Quantitative Methods in Poverty Appraisal. University of Toronto, Toronto, Ontario, Canada. http://dx.doi.org/10.1016/ j.worlddev.2005.10.020

Parry, J. E., A. Hammil, and J. Drexhage. 2005. Climate change and adaptation. International Institute for Sustainable Development, Winnipeg, Manitoba, Canada. [online] URL: http://www.iisd. org/pdf/2005/climate adaptation.pdf

Reid, P., and C. Vogel. 2006. Living and responding to multiple stressors in South Africa-glimpses from KwaZulu Natal. Global Environmental Change 16:195-206. http://dx.doi.org/10.1016/j.gloenvcha. $\underline{2006.01 .003}$

Rule, S., R. Aird, S. Drimie, M. Faber, T. Germishuyse, A. Jordaan, P. Kok, B. Roberts, M. Roefs, H. Schonfeldt, C. Schawbe, M. van Lieshout, J. Van Zyl, and H. Vermeulen. 2005. Report on survey in Sekhukhune to pilot the development of a food insecurity and vulnerability modelling system (FIVIMS) for South Africa. HSRC Client Report, Pretoria, South Africa.

Schulze, R. E., editor. 2005. Climate change and water resources in southern Africa. WRC Report No. 1430/1/05. Foundation for Water Research, Marlow, UK.

Schulze, R. E., and P. D. Tyson. 1997. Impacts of global climate change in a hydrologically vulnerable region: challenges to South African hydrologists. Progress in Physical Geography 21 (1):113-136. http://dx.doi.org/10.1177/0309133397 $\underline{02100107}$

Scoones, I. 1998. Sustainable rural livelihoods: a framework for analysis. IDS working paper 72, Institute for Development Studies, Brighton, UK.
Sen, A. 1981. Poverty and famines. Claredon, Oxford, UK. http://dx.doi.org/10.1093/0198284632 .001 .0001

Silva, J. A., S. Eriksen, and Z. A. Ombe. 2010. Double exposure in Mozambique's Limpopo River Basin. Geographical Journal 176(1):6-24. http://dx .doi.org/10.1111/j.1475-4959.2009.00343.x

Smit, B., I. Burton, R. J. T. Klein, and R. Street. 1999. The science of adaptation: a framework for assessment. Mitigation and Adaptation Strategies for Global Change 4:199-213. http://dx.doi.org/10. 1023/A:1009652531101

Smit, B., I. Burton, R. J. T. Klein, and J. Wandel. 2000. An anatomy of adaptation to climate change and variability. Climatic Change 45:223-251. http: //dx.doi.org/10.1023/A:1005661622966

South African Development Community; Food, Agriculture and Natural Resources (SADC FANR). 2003. Towards identifying impacts of HIV/AIDS on food insecurity in Southern Africa and implications for response: findings from Malawi, Zambia and Zimbabwe. SADC FANR Vulnerability Assessment Committee, Harare, Zimbabwe.

Stronkhorts, L., and D. Pretorius. 2008. LADA country report - South Africa. Presented to $U N$ Convention to Combat Desertification Seventh Session of the Committee for the Review of the Implementation of the Convention (CRIC 7), 3-14 November 2008, Istanbul, Turkey.

Tefera, A. N., M. D. Gayathri, M. P. Emmanuel, M. Clerkson, M. Margaret, M. Chrispen, and S. Oneile. 2004. Goats production and livelihood systems in the Sekhukhune District of the Limpopo Province, South Africa: opportunities for commercialising goats and their by-products. Working Document Series 118. International Centre for Development Oriented Research in Agriculture (ICRA), Wageningen, The Netherlands, Limpopo Department of Agriculture (LDA), Polokwane, South Africa, Agriculture Research Council - Sustainable Rural Livelihoods (ARC-SRL) Division, Pretoria, South Africa.

Thomas, D., H. Osbahr, C. Twyman, N. Adger, and B. Hewitson. 2005. ADAPTIVE: adaptations to climate change among natural resource-dependent societies in the developing world across the Southern African climate gradient. Technical 
Report 35, Tyndall Centre for Climate Change Research, University of East Anglia, UK.

UNAIDS. 2006. Report on the global AIDS epidemic. UNAIDS, Geneva, Switzerland.

Van Wyk, A. E., and P. Van Wyk. 1997. Field guide to trees of southern Africa. Struik, Cape Town, South Africa.

Victor, J., S. Siebert, D. Hoare, and B. Van Wyk. 2005. Sekhukhuneland grasslands: a treasure house of biodiversity. FAO Crop and Grassland Service. [online] URL: http://www.fao.org/ag/AGP/agpc/doc/ Show/SAfrica/sapaper/saessay.htm

Watts, M. J. 1983. Silent violence: food, famine and peasantry in Northern Nigeria. University of California Press, Berkeley, California, USA.

Westerhoff, L., and B. Smit. 2009. The rains are disappointing us: dynamic vulnerability and adaptation to multiple stressors in the Afram Plains, Ghana. Mitigation and Adaptation Strategies for Global Change 14:317-337. http://dx.doi.org/10.10 07/s11027-008-9166-1

Zanner, R., S. Drimie, G. Ziervogel, K. Tlabela, R. Mokoena, S. Rule, and Z. Langa. 2004. Institutional analysis of Sekhukhuneland ISRD node. FIVIMS ZA report. University of Cape Town, Human Sciences Research Council, and University of Witwatersrand, South Africa.

Ziervogel, G., and S. Drimie. 2008. The integration of support for HIV and AIDS and livelihood security: district level institutional analysis in southern Africa. Population and Environment 29:204-218. http://dx.doi.org/10.1007/s11111-0080066-9

Ziervogel, G., and A. Taylor. 2008. Feeling stressed: integrating climate adaptation with other priorities in South Africa. Environment 50 (2):32-41. http://dx.doi.org/10.3200/ENVT.50.2.32-41 